\title{
Role of the Human Rights Ombudsman in Ensuring Good Administration in Slovenia ${ }^{1}$
}

\author{
Kornelija Marzel \\ Human Rights Ombudsman of the Republic of Slovenia, Ljubljana, Slovenia \\ kornelija.marzel@varuh-rs.si \\ https://orcid.org/0000-0001-6665-5358
}

Received: 19. 9. 2018

Accepted: 18. 2. 2019

\section{ABSTRACT}

According to the Constitution of the Republic of Slovenia and the Human Rights Ombudsman Act, the Slovenian Ombudsman is established to protect human rights and fundamental freedoms in relation to public authorities. It is important that the Ombudsman not only complies with the provisions of the Constitution and international legal acts, but that when intervening, the Ombudsman may invoke the principles of fairness and good administration. The purpose of the article is to contribute to the understanding of good administration and related circumstances for the respect or violation of human rights. The article is based on the idea that by applying the principles of good administration, public authority undermines the public belief that bureaucracy is an end in itself and is in a dominant position. With these principles, public authority focuses on parties which realise their rights and enjoy their freedoms through the principles and postulates of a democratic society. Both theoretical and empirical research methods were used in the preparation of the article. The analysis of complaints to the Ombudsman aimed to verify the compliance of normative, theoretical bases with actual practice, and to establish the basis for evaluating the existing model of the Slovenian Ombudsman, all in the context of the study of good administration. The results together with theoretical findings facilitated the verification that in practice, public authorities most frequently violate the principles of good administration and that the Ombudsman may significantly contribute to good administration within their powers. The findings of this article are an original contribution to understanding ombudsmen and their role in different countries.

Keywords: good administration, human rights, ombudsman, public authority, Slovenia

JEL: $H 38, K 38$

1 The article stems from the doctoral dissertation of Kornelija Marzel, titled Analysis of Human Rights Ombudsman Institutions with an Emphasis on Legality and Legitimacy, defended at the Faculty of Administration of the University of Ljubljana on 15 September 2016 under the mentorship of assoc. prof. Mirko Pečarič, PhD, and prof. Polonca Kovač, PhD. 


\section{Introduction}

The Human Rights Ombudsman of the Republic of Slovenia (the Ombudsman) as an institutionalised informal form of human rights protection was introduced to our legislation with the Constitution of the Republic of Slovenia (the Constitution). Such an institution had not existed in the previous social system. There was the Council for the Protection of Human Rights and Fundamental Freedoms within which members investigated violations of human rights honorarily and without payment. As a new democratic country was born, its values, human rights and freedoms explicitly stated in the preamble to the Basic Constitutional Charter on the Independence and Sovereignty of the Republic of Slovenia and the Constitution required special protection.

We learned from the past that mere incorporation of human rights in the highest legal acts is not enough. Efficient and accessible mechanisms to protect human rights must also be provided (Rovšek, 2013). Friendliness, accessibility, informality, simplicity and being free of charge are the characteristics that distinguish an ombudsman from other formal forms of human rights protection. A look to history shows that the first institution of an ombudsman was established in Sweden on the basis of the Swedish constitution from 1809, while the ombudsman actually began practising in 1810.

The ombudsman initially primarily dealt with assessing compliance of public authority with regulations. At that time, legality was the ombudsman's primary assessment standard, while legitimacy, good administration and the protection of human rights followed in subsequent development periods.

In a certain sense, the principles of good administration applied and referred to by the Slovenian Ombudsman are an open framework of common understanding of what is deemed good in relation to public authority, what is accepted as permissible and what is expected as desired in the realisation of goals which fostered the establishment of an individual institute of public authority in view of the context of the social and political situation of the decision making of public authority. By referring to the said principles, fairness is introduced in the work of public authority, since these principles are the framework for the understanding and also restricting behaviour that public authorities must not cross. Good administration is actually the foundation of fairness.

Formal supervision of decisions of public authorities is carried out by appeal bodies, courts and others, while informal supervision is carried out by the Ombudsman. Together, they guide the future work of public authority towards new horizons of legality and legitimacy, and the respect for human rights and freedoms.

The article assumes that the Ombudsman significantly affects the definition and development of good administration. When assessing the work of public authority, the Ombudsman has significant powers, particularly as it does not merely establish whether the administration and other parts of public author- 
ities comply with regulations, but, in relation to violations of human rights, also focuses on actions according to the principles of fairness and good administration. The hypothesis that the principles of good administration are not only welcome but an essential supplement to existing principles of the decision making of public authority in terms of a combination of various approaches, especially to protect human rights, is followed by analysis and discussion to study forms of so-called poor administration in Slovenia, and also by taking into account theoretical bases, by recommendations to arrange the principles of good administration in Sloveniade lege ferenda.

The discussion of the topic which is the subject of the article was based on the application of various methods, particularly theoretical but also empirical methods.

To show the actual practice of an ombudsman and the realisation of the model of protection against poor administration, annual reports on the work of the Ombudsman for 2016 and 2017 were analysed, and complaints to the Ombudsman regarding which violations of the principles of fairness and good administration had been established for the two years were studied. The aim was to verify the compliance of normative and theoretical bases with actual practice, and to establish the basis for critically evaluating the model of the Slovenian Ombudsman. Due to the limitation of the article, the analysis only included the national ombudsman. Comparisons with related institutions are recognised as possibilities for further research.

\section{Study and results}

\subsection{Legality and legitimacy}

As previously mentioned, the first ombudsmen dealt primarily with illegal behaviour of, at first only, the executive branch of public authority and later also wider. In subsequent development periods, it was widely believed that primarily the courts were meant to supervise legality, and that the supervision by ombudsmen, which are an informal form of the protection of individual against public authority, should, in addition to the aforementioned areas, include the assessment whether the behaviour of public authority was legitimate.

Both legality and legitimacy may be explained within the concept of good administration. This concept is a general term for legal, professional, prudent, fair and decent behaviour of public authorities. Legality means compliance with regulations, while legitimacy means justification, acceptability and fairness of public authority. (Non)Legality is slightly easier to explain, as there are objective criteria for that; legitimacy is harder, which may be deduced from its definition. Teršek (2014, p. 54) labels it as "quality which transforms pure power to justified authority". The core of legitimacy is composed of the ratio between coercion and free will. In this context, the same author believes that human rights are a "minimum normative standard of justification, acceptabili- 
ty and legitimacy of public authority, institutions, rules and binding decisions" (Teršek, 2014, p. 31). The foundation of legality is established with the establishment of public authority, which does not necessarily lay down the foundation of legitimacy. The legitimacy of the behaviour of public authority (determined with regulations, making it legal) is only provided when regulations stem from morality, ethics and customs, which means that they are accepted and respected by society.

As democratic society developed, the actions of ombudsmen moved from the assessment of the legality and legitimacy of the behaviour of public authority to their good administration and respect for human rights. The significance of an ombudsman in human rights protection cannot be denied, as established by Kaučič (2008), Kocjančič (2009), Bavcon (2013), Rovšek (2002), Remac (2013), L. Reif (2004) and others. The said role of an ombudsman is distinctly characteristic of countries without a tradition of democracy, which have to pay special attention to legality and legitimacy, and fundamental human rights and freedoms to establish and maintain democratic standards. The role of ombudsmen in the protection of human rights is not contested anywhere in the world. International promotion of human rights and activities of national institutions for the protection of human rights ${ }^{2}$, which, in individual countries, guide, train and educate in relation to human rights, raise awareness of the public and spread knowledge thereof, facilitating the exercise of human rights and reducing their violations.

According to Rovšek (2002), it should be pointed out that almost every "irregularity and procedural error may be defined as a violation of Convention rights, for example in relation to fair proceeding as stated in Article 6 of the Convention for the Protection of Human Rights and Fundamental Freedoms. Therefore, it is not appropriate to wonder about the significance and role of ombudsmen in the protection of human rights, even in countries with developed parliamentary democracy, where ombudsmen develop standards of good administration and dedicate themselves to new generations of human rights which are not fundamental (e.g. the right to clean environment), contributing to good administration and higher human rights standards.

\subsection{Poor administration as a violation of human rights}

Democratic development of a country requires decisions by public authority, which are based on legality, correctness, decency, effectiveness and efficien$c y$, and respect the postulates of the rule of law and the principle of good administration. The aforementioned principles are crucial, as public authorities frequently state regulatory framework as an excuse or apology for inactivity in the sense that certain situations are not regulated and that there is nothing that can be done, which is not true, as the general norm that public authority should act professionally and in accordance with the principles of

2 These are national institutions in the field of the promotion and protection of human rights, which operate on the basis of the Principle related to the Status of National Institutions - The Paris Principle) adopted by the UN. In 2018, the Slovenian Ombudsman requested to obtain the said accreditation. 
good administration is forgotten. The said principles may be the basis of extraordinary solutions in situations not foreseen by regulations (Rovšek, 2002, p. 143). They may be used to solve special situations, circumstances or cases, when, for example, administrative silence is replaced by successful mediation, enabling administrative activity to become legal, legitimate, suitable and efficient public authority (Kovač, 2012).

In good and poor administration, there is a dilemma regarding the standards of such behaviour of public authority. The fact that in Slovenia the phrase "good administration" is only used in the Human Rights Ombudsman Act and the Public Administration Development Strategy 2015-2020 is very interesting. In other countries, the right to good governance, good administration, good administrative behaviour, maladministration and other related terms, which generalise either good or poor governance or either good or bad administration, are used. In this article, good administration is discussed in its narrower sense as part of wider good governance. Poor administration is defined as any questionable behaviour of public authority, which may include administrative errors, or error in ethical or moral aspects (indecency, unresponsiveness, inappropriateness). The main characteristic of poor administration everywhere is that it is not always illegal.

Good administration and the right to a fair trial without error may be referred to when "authorities make the exercise of individuals' rights difficult incorrectly and unjustifiably, without such behaviour being in contravention of regulations" (Grad etc., 1996, p. 331). As previously mentioned, it should be pointed out that good administration and fairness stem from international agreements and international principles: they refer to openness, transparency, accessibility, responsiveness, ethical behaviour, fairness, economy, and effectiveness and efficiency, and in this respect, they do not receive national protection but also international protection.

Ethical rules are the lever of good administration. These are high standards of the behaviour of public authority, which, in a certain sense, supplement and upgrade legal standards. The public expect public authority to behave in a legal and legitimate manner and in line with morality, ethics and customs. In various acts, the standards of good administration are only stated individually and are not substantively improved, which leads us to believe that democratic society and public expectations regarding the behaviour of authorities constantly evolve.

The opposite of good administration is poor administration. The pioneer of its definition in relation to the work of ombudsmen is Richard Crossman who called it maladministration and characterised it with partiality, neglect, carelessness, negligence, delays, incompetence, malevolence and other characteristics (Harlow and Rawlings, 2009).

In 1998, the European Ombudsman shaped the term of good administration as a counterbalance to poor administration (The European Ombudsman, 1999). According to the European Ombudsman, good administration consists of three aspects: material (which comprises legality, equality, objectivity and 
others), procedural (refers to the course of proceedings in accordance with procedural rules to protect the rights of clients and efficient decision making) and direct obligations of authorities to clients (particularly requirements for clear and suitable information, friendliness, acknowledgement of errors and apologising for them).

In this regard, it must be emphasised that limited good administration addresses higher expectations than suitable or fair administration which inly includes minimum standards, as found by Addink (2015, p. 44).

Pečarič $(2011$, p. 535) points out the lack of definition of the content of good administration. It is a legally undefined term which covers "procedural and material elements" which are not necessarily legally enforceable. According to said author, it is used as a standard of "administrative fairness", transparen$c y$, openness and clarity of procedures, to correct the quality of the ratio between public authority and citizens, which thus "changes from authoritative and centralised to decentralised and participative functioning of the state" (Kovač and Leben, 2015, p. 4).

Certain authors (Koprić, Musa and Lalić, 2011) state gradualness in the development of good administration: at first, it was defined with ethical standards of behaviour and later became a human right explicitly stated in the Charter of Fundamental Rights of the European Union.

Good administration as a working method "is a mix of entitlements of democratic relations with clients and efficient administration for legally foreseeable and responsible manner of the execution of public authority and public services", as believed by Tomaževič and Aristovnik (2015, p. 2).

It is also essential to increase the possibility of concluding agreements, settlements and mediations, as pointed out by the Ombudsman and discussed in relation to the development of alternative forms of dispute resolution by Remac (2014), L. Reif (2004), Pečarič (2016), Kovač $(2014,2016)$, Dragos and Neamtu (2014), and others. Good administration could be developed in this way, which "is not only minimum formalism but a participatory and efficient implementation of public policies with active inclusion of individual members of society in public administration" (Kovač, 2016, p. 91).

In reference to all said authors and stemming from findings of theoretical studies, the conclusion is that good administration is based on the principles of legality, openness, transparency, participation, responsibility, efficiency and connection. Prompt response to social needs and equality of both sides, public authority and clients, are key elements of good administration, which is all the essence of modern democratic systems (Lozina and Klarić, 2012). The responsibility of ombudsmen is to contribute with their proposals and recommendations to the formation of the so-called partner relationship between public authority and individuals, and co-shape public authority that will follow legal proceedings (administrative, civil, criminal and other), whose rules and safeguards limit the power of public authorities, and the principles of good administration in a way that respects human rights and freedoms. 


\subsection{General characteristics, emphases and guidelines of good administration on an international scale}

The right to good administration is not explicitly defined in Slovenian legal regulations; only two previously mentioned documents refer to it. Due to the aforementioned reasons, the Slovenian Ombudsman, when establishing violations of good administration, frequently refers to findings of individual experts in this field, and international legal acts which go beyond relating good administration with legal and legitimate behaviour of public authorities. All these procedures of authorities must be carried out with particular sensitivity and in a way that respects personality, the situation and human rights of each individual. For these reasons, international documents which include provisions on good administration are presented briefly below.

European Union: The Treaty on European Union and the Treaty on the Functioning of the European Union both contain provisions on good administration. Provisions on good administration are contained in Article 20 of the Treaty on the Functioning of the European Union (the option to appeal to the European Ombudsman) and in Article 298 of the same document (regarding expectations of an open, efficient and independent European administration), as well as other places.

Article 41 of the Charter of Fundamental Rights of the European Union explicitly acknowledges the right to good administration. The European Code of Good Administrative Behaviour (the European Code) approved at the proposal of the European Ombudsman by the European Parliament, the set of principles of public administration for EU civil servants published by the European Ombudsman in 2012, and the updated version of the European Code from 2015 include ethical standards to be respected by the public administration of the European Union and guidelines on practical actions for better efficiency, transparency and responsibility. The aforementioned documents are not binding but have a dual meaning. On the one hand, they define the culture of the functioning of the EU bodies and Member States when they apply European Union law, supporting citizens in their justified expectations regarding the behaviour of the said bodies. According to the Charter of Fundamental Rights of the European Union, every person has the right to have their affairs handled well by bodies of the EU (and by Member States in situations when they apply European Union law). On the other hand, these acts stimulate Member States to create conditions and circumstances for good administration within their borders.

The adoption of the Law of Administrative Procedure of the European Union proposed to the European Commission by the European Parliament in 2013 and in 2016 with the Resolution ${ }^{3}$, which would contribute to good administration, as the rules of administrative law would be codified. Certain procedural rules and rights would be available to persons who encounter EU administration, the rules of good administration would be included in a single act (and

3 The Resolution with Recommendations to the Commission on a Law of Administrative Procedure of the EU (2012/2024(INL)) adopted on 13 January 2013 and the Resolution for an 
not various sources like they are now), and the legitimacy of the EU and the confidence of citizens in its administration would strengthen. The adoption of the act would facilitate convergence with national administrative law and affect the standards of good administration in national environments (European Parliament, 2013). It should be noted, however, that the formal procedure for the adoption of the EU administrative law has not yet begun and that the proposal of the European Parliament has only a non-binding nature of the recommendation.

Council of Europe: In 1977, the Committee of Ministers adopted the Resolution on the Protection of the Individual in Relation to Acts of Administrative Authorities (77) $31 .{ }^{4}$ Its key purpose was to protect individuals against authoritarian behaviour of administrative authorities. In 2007, the Committee of Ministers further adopted the Recommendation CM/Rec 7 on good administration $^{5}$ the appendix to which contains the Code of good administration with a very detailed description of the standards of good administration. None of the said acts is binding for Member States of the Council of Europe, but they urge them to provide good administration, which may be done by adopting suitable standards and establishing a system to measure their performance. All these activities would increase responsibility, the results of administration would improve, the satisfaction of individual would grow, the role of administration would strengthen and the confidence in its work would be boosted.

The Venice Commission (European Commission for Democracy through Law, 2011 , p. 6) places good governance and good administration in a set of sustainable development theories with the following characteristics: legality, openness, transparency and responsibility, fairness and equality, the use of counselling and participation mechanisms, effectiveness and efficiency, clear, transparent and useful legislation, consistency and clarity when designing policies and high standards of ethical behaviour.

\subsection{Good administration in national legislation}

Slovenian legislation explicitly states the term good administration only in one legal act, i.e. the Human Rights Ombudsman Act (ZvarCP), Article 3 of which stipulates that "In their work, the Ombudsman shall comply with the provisions of the Constitution and international legal acts on human rights and fundamental freedoms. When intervening, the Ombudsman must invoke the principles of equity and good administration". Equality is one of the fundamental constitutional principles. Together with the principles of a legal and social state, it means the basis of fairness in society. Within the aforementioned intervention, the Ombudsman may propose exceptional, sensible and suitable solutions, while remaining in the zone of legality and equality before the law, and recommend amendments to legislation. The Ombudsman con-

open, efficient and independent European Union administration (2016/2610(RSP)) adopted on 9 June 2016.

4 Resolution (77) 31 on the Protection of the Individual in Relation to Acts of Administrative Authorities (Council of Europe, 1977.

5 Recommendation CM/Rec 7 on good administration (Council of Europe, 2007) 
tributes to informal practices of the behaviour of public authorities to become legally binding, which may occur in situations when the Ombudsman recognises injustice in failure to comply with the principles of good administration and therefore, proposes an act that makes good administration binding.

The term good administration is also defined in the Public Administration Development Strategy 2015-2020 which states on page 3 that "citizens as business entities need a flexible and responsive public administration which will behave in a transparent, professional and responsible manner, and comply with the principles of good administration". The Strategy foresees public administration to be modernised so that it will comply with the principles of good administration. Good public administration should contribute to general welfare and boosting the confidence of the public in its work. As elements of good administration, the Strategy states individual principles and values: transparency, responsibility, participation and others. The said elements refer to the rights citizens must have in relation to public services, some of them are included in the Constitution, procedural rules which regulate individual legal fields, in the Public Employees Act, the Code of Conduct for Civil Servants, the Code of Conduct for Civil Servants in State Bodies and Local Community Authorities, and elsewhere.

This brings up the question about the content of good administration. According to Pečarič (2008, p. 202), "the principle of good administration may be explained as the umbrella principle of the whole public administration (or the public sector) to behave according to the principles of legality, legal certainty and predictability, political neutrality, focus on users, openness and transparency, quality, effectiveness and efficiency, and should not only include the protection of human rights and fundamental freedoms, but also prudence, effectiveness, efficiency, proportionality, rationality and responsiveness of the functioning of public administration". According to the Slovenian regulation of the Ombudsman, good administration is available in the broadest sense of the word; its infringement is not necessarily a violation of regulations. This may also be deduced from Article 45 of the ZVarCP, which stipulates that the Ombudsman provides state authorities, institutions and organisations with public authority with proposals to improve their operations and treatment of clients. However, the Ombudsman may intervene in cases of poor administration, regardless of their primary task (to protect human rights), since good administration is crucial for the exercise of human rights and freedoms.

\subsection{Analysis of forms of poor administration in the practice of the Slovenian Ombudsman}

The subject of the Ombudsman's work is the protection of human rights and fundamental freedoms which are violated by illegal and illegitimate behaviour or poor administration, which is not studied and established by the Ombudsman, as they are limited to public sector bodies that carry out the tasks of public authority. According to the Constitution and the ZvarCP, the Ombudsman supervises state authorities, local self-government authorities and holders of public authority. 
Within the scope of the analysis, reports on the work of the Ombudsman for 2013, 2014, 2015, 2016 and 2017 were studied, particularly cases and complaints regarding which the Ombudsman established violations of the principles of good administration and fairness in 2015, 2016 and 2017.

The research showed the following limitations:

- a large number of complaints handled by the Ombudsman, over 3,000 per year on average;

- the system of concluding justified complaints by stating the type of the violation established and the violator was only introduced in 2015 , which prevents retrospective comparisons;

- the manner of concluding complaints with a description of the established violation of the principles of good administration or fairness, which sometimes required a physical insight in a case prior to the capturing and analysis of data, which was followed by uniform recording on a pre-prepared form;

- the Ombudsman's not completely clear and focused recommendations on how a public authority should behave to comply with the principle of good administration, which could significantly contribute to the content of the said principle.

\subsection{Analysis results}

Annual reports on the work of the Ombudsman for the term of the current Ombudsman Vlasta Nussdorfer (2013-2017) show the following data on closed cases either handled at the Ombudsman's initiative or on the basis of received complaints. The closed cases аге all cases handling of which was completed with the end of each year.

Table 1: Ratio between the number of all closed and justified cases by years*

\begin{tabular}{|c|c|c|c|c|c|}
\hline Cases Year & 2013 & 2014 & 2015 & 2016 & 2017 \\
\hline Closed & 3737 & 3181 & 3008 & 2722 & 2627 \\
\hline Justified & 893 & 684 & 457 & 357 & 386 \\
\hline $\begin{array}{l}\text { Level of } \\
\text { justification }\end{array}$ & $23.9 \%$ & $21.5 \%$ & $15.2 \%$ & $13.1 \%$ & $14.7 \%$ \\
\hline
\end{tabular}

The level of justification, i.e. in which the Ombudsman established irregularities, violations of human rights and behaviour in contravention of the principle of good administration, has been around 15 per cent for the past three years. Prior to that, the level of justification had been higher. However, it was established that it was particularly down to the fact that the Ombudsman established a new working method and a system of concluding complaints 
in 2015 in which the type of violation and the violator (authority) are recorded in each justified case. The aforementioned findings will facilitate detailed analyses, comparisons and more accurately focused recommendations of the Ombudsman.

Justified cases in which violations of the principles of good administration and fairness were established are shown below, at first in absolute numbers (Table 2) and then in shares (Table 3). They are related to this article, so only these established violations are compared. It is crucial to take into account the fact that such a comparison and analysis are not possible for previous years, since justification was established and recorded only generally, which did not enable the actual situation regarding the extent of a certain problem or the number of individual violations to be shown.

Under current regulation, the results of the analysis allow consideration of urgent changes to legislation and existing practice of the functioning of public authorities, particularly where violations occur most frequently.

Table 2: Ratio between the number of all violations and established violations of the principles of good administration and fairness*

\begin{tabular}{|c|c|c|c|}
\hline Year & 2015 & 2016 & 2017 \\
\hline Good administration & 63 & 78 & 114 \\
\hline Fairness & 3 & 14 & 15 \\
\hline All** & 504 & 374 & 446 \\
\hline
\end{tabular}

* The data are shown without the field of the National Prevention Mechanism.

** The data signify total violations of human rights established in individual years.

Source: annual reports on the work of the Ombudsman for 2015, 2016 and 2017

The article also shows the importance of the comparison of the shares of all violations and violations of the principle of good administration by years.

Table 3: Ratio between the share of all violations and established violations of the principles of good administration and fairness*

\begin{tabular}{|c|c|c|c|}
\hline Year & 2015 & 2016 & 2017 \\
\hline Good administration & $12.5 \%$ & $20.8 \%$ & $25.56 \%$ \\
\hline Fairness & $0.59 \%$ & $3.7 \%$ & $3.36 \%$ \\
\hline All & $100 \%$ & $100 \%$ & $100 \%$ \\
\hline
\end{tabular}

* The data are shown without the field of the National Prevention Mechanism.

Source: annual reports on the work of the Ombudsman for 2015, 2016 and 2017

The urgency of further research of violations of the principles of good administration and fairness is notably highlighted, as it was established that public authorities most frequently violate these principles related particularly to the 
right to a fair trial. To understand the data shown in the article (limitation to individual years and violations), it should be explained why the numbers of justified cases, violations and violators do not match. More cases handled included the identification of several violations and violators. The answer also lies in the circumstances of the work of the Ombudsman (already presented) and public authorities. They carry out many demanding, diverse and related tasks, and the fact of frequent and insufficiently thought out amendments to legislation extending to fields of work of various authorities may not be ignored either.

Also important is the study of cases handled by the Ombudsman at their own initiative, in which violations of the principle of good administration were established, as shown in Table 4.

Table 4: Ratio between violations of good administration and the manner of procedure instigation

\begin{tabular}{lccc|}
\hline \multicolumn{1}{c}{ Year } & $\mathbf{2 0 1 5}$ & $\mathbf{2 0 1 6}$ & $\mathbf{2 0 1 7}$ \\
Procedure & 62 & 76 & 108 \\
\hline Upon received complaint & 1 & 2 & 6 \\
At own initiative & 63 & 78 & 114 \\
Total & Source: own & & \\
&
\end{tabular}

Regarding the violation of fairness, all justified cases were handled on the basis of received complaints; the total number of such violations in 2015, 2015 and 2017 is 32 .

The analysis further researched the segment of violators of the principles of fairness and good administration (Table 5).

Table 5: Violators of fairness and good administration by years

\begin{tabular}{|c|c|c|c|}
\hline Year & 2015 & 2016 & 2017 \\
\hline State administration & 45 & 50 & 79 \\
\hline Other state authorities & 6 & 4 & 9 \\
\hline Local self-government & 10 & 7 & 11 \\
\hline Holders of public authority & 2 & 15 & 27 \\
\hline Other & 0 & 2 & 3 \\
\hline
\end{tabular}

Source: own

The results of the analysis in the years in question show that all justified cases (and violations) handled by the Ombudsman most violations were violations of the principle of good administration, i.e. unsuitable cooperation and coordination between authorities, failure to reply to received letters (ministries, 
inspectorates, mayors), unsuitability, lack of comprehension and lack of harmonisation of provided information, lengthy decision-making procedures, unresponsiveness of authorities, delays in procedures, failure to fulfil promises and commitments, unclear competences and powers of individual authorities and institutions, failure to adopt internal acts, failure to fulfil the obligation to explain, and others. Also important is the finding that shows that the share of cases of established violations of the principle of good administration has been increasing with years, which is shown in Table 5, and that the highest share of violators are from state administration which includes ministries, bodies affiliated to ministries, government services, administrative units and other state administration authorities that carry out the tasks of state administration at the local level, such as branches of inspectorates, defence and land survey services, financial administration and others.

In the cases and complaints in question, the Ombudsman addressed to competent authorities their specific proposals and positions, which included clearly defined established irregularities and violations, proposals to eliminate the existing situation and proposals for suitable behaviour in the future. Generally, the Ombudsman's proposals for potential amendments to legislation and improvements to existing practices of the authorities towards good administration were provided in relevant annual reports on the work of the Ombudsman, the realisation of which is reported and discussed in the next annual report.

\subsection{Other issues related to the findings of the analysis}

Despite limitations, the results of the analysis are representative and obtained in this manner for the first time. Together with theoretical findings, they facilitate verification of how public authorities carry out their mission and powers, and follow the Public Administration Development Strategy and postulates of the modern democratic social system, while taking into account the principle of good administration. The results are the substantive basis of the definition of good administration and of its potentially greater inclusion in the legislative framework. The principles of good administration also include broader principles, some of which are part of the Constitution and individual procedural regulations, while others are such that failure to comply with them is not necessarily a violation of legal regulations.

The information that, among all potential violations and irregularities, the Ombudsman established most violations of the principles of good administration most frequently caused by state administration authorities may be explained by the fact that administrative procedures are the most frequent legal proceedings most individuals are involved in and in which decisions are made by state administrative authorities. It is important that the Ombudsman's identification of violations of the principle of good administration comprises irregularities which are a violation of legal regulations (e.g. exceeding the statutory deadline to issue a decision) and those which are not necessarily such a violation. Both cases undoubtedly refer to the behaviour of public au- 
thorities which is in contravention of the principle of good administration; however, legal remedies are available to individuals in cases of violations of legislation before national and international public authority. Most unsuitable behaviour of public authorities, which is not unlawful but is in contravention of the principle of good administration, remains unsanctioned but still poses inconveniences and difficulties, and is a violation of the principle of good administration and frequently prevents the exercise of certain human rights and freedoms. Therefore, the Ombudsman's power referred to in Article 45 of the ZVarCP, which stipulates that the Ombudsman may submit proposals for improving operations and the treatment of clients to state authorities, institutions and organisations (including municipalities, taking into account their position and tasks related to public authority) with public authority, is all the more important.

\section{Conclusion}

While there are many rules, principles and procedural requirements, many violations of human rights still occur in decision-making procedures on the rights, obligations and legal entitlements of clients, and in the provision of goods and services, as established by the Ombudsman. These arise not only from illegal and illegitimate behaviour of public authorities but are frequently the consequence of behaviour of public authority that is in contravention of the principle of good administration.

The Ombudsman was actually established due to the need to limit public authorities' self-will and for them to perform their functions in a way that ensures legality, legitimacy, good administration and respect for human rights and freedoms. The findings of the Ombudsman are a reflection of the actual needs of the people of Slovenia, and the Ombudsman's success stories are alerting to, and eliminating, actual violations of public authorities.

The research shows that the Ombudsman in their work records violations of the principle of good administration more frequently than other potential violations. Also, in relation to the efforts of the European Ombudsman to establish good administration, the instruction of the Slovenian Ombudsman to refer and introduce similar standards in the work of public authority is particularity important. The principle of good administration supplements existing systems, as it legitimises the purpose of the decision making of public authority. Such systems may be formally legal without it but are in contravention of good administration and as mentioned, may be a violation of the right to a fair trial according to the ECHR.

On the basis of what is explained in the article, it may be confirmed that the institution of the Ombudsman significantly contributes to the definition and development of good administration. When assessing the work of public authority, the Ombudsman has significant powers, particularly as it does not merely establish whether public authority complies with regulations, but, in relation to violations of human rights, also focuses on actions according to 
the principles of fairness and good administration. Therefore, the Ombudsman does not only eliminate violations and systemic irregularities with their recommendations, but attempts to change the behaviour of public authorities towards new horizons of good administration over a certain period. Alternative forms of dispute resolution, concluding agreements, settlements, mediations and the implementation of the principles of a participatory society are also being pursued .Many problems, irregularities, violations and disputes could be resolved merely by individuals having the opportunity to say how they see things, i.e. being actively included in development and resolution of their situation.

The contribution of the Ombudsman to the development of modern good administration is significant. However, shifts in this direction do not depend only on the ombudsman but on public authority, i.e. whether they see the sense of the Ombudsman's findings, proposals, recommendations and positions, and the potential for good administration to develop, which is crucial to ensuring human rights and freedoms.

The objective of the work of the Ombudsman is to achieve the elimination of violations; therefore, the Ombudsman strives for amicable resolutions with settlements, mediations or other forms of alternative solutions. In this field, the Ombudsman's activity could be enhanced, particularly in light of the finding that a combination of recommendations ${ }^{6}$ and powers of public authority has proven in practice rather optimal. The European Ombudsman strives to achieve that the standards of good administration be introduced to the work of EU civil servants. Therefore, the instruction to refer to, and introduce, similar standards to the work of the public sector in Slovenia is sensible.

Perhaps we should consider adopting a code of good administration by civil servants in Slovenia; prior to that, however, a detailed analysis of the actual situation should be carried out in relation to the findings of the Ombudsman and other similar supervisory institutions. Defining the content of the standards of good administration is essential for the establishment of good administration which must be defined as better legislation and part of broader good governance. The option to directly refer to the right to good administration referred to in Article 41 of the Charter of Fundamental Rights of the European Union, ${ }^{7}$ although Slovenian legal regulations do not explicitly define it.

6 According to Article 7 of the ZvarCP, the Ombudsman may address proposals, opinions, criticisms or recommendations to competent authorities, which are obliged to discuss, and reply to, them. In this case, the nature of the Ombudsman's powers is recommendatory.

According to Article 23a of the Constitutional Court Act, the Ombudsman may address a proposal to the Constitutional Court for a review of the constitutionality or legality of regulations or general acts issued for the exercise of public authority, if they deem that a regulation or general act issued for the exercise of public authority encroaches unacceptably on human rights or fundamental freedoms. In this case, the Ombudsman's powers have the power of public authority.

7 Article 15 of the Constitution of the Republic of Slovenia stipulates that no human right or fundamental freedom regulated by legal acts in force in Slovenia may be restricted on the grounds that this Constitution does not recognise that right or freedom or recognises it to a lesser extent. 


\section{References}

Addink, G. H. (2015). Good Governance in the EU-Member States: A comparative, interdisciplinary study on the interpretation and application of good governance in the EU member states and in the different functions of the government bodies. At <https://www.ris.uu.nl/ws/files/18826324/Final_ version_september_2015.pdf>, accessed 17 December 2018.

Bavcon, L. (2013). Spoštovanje človekovih pravic - nikoli dosežen ideal. In J. Rovšek and L. Kalčina, eds., 20 let Zakona o varuhu človekovih pravic 19932013. Ljubljana: Human Rights Ombudsman of the Republic of Slovenia, pp. 32-35.

Charter of Fundamental Rights of the European Union, OJ C 303, 14. 12. 2007.

Constitution of the Republic of Slovenia. (2016). Ljubljana: IUS SOFTWARE, GV Založba.

Council of Europe, 20. 6. 2007. Recommendation CM/Rec (2007)7 of the Committee of Ministers to member states on good administration. At <https://wcd.coe.int/ViewDoc.jsp?id=1155877>, accessed 15 April 2015.

Council of Europe, 28. 9. 1977. Res (77)31E on the protection of the individual in relation to the acts of administrative authorities. At <https://wcd.coe.int/ ViewDoc.jsp?Ref=Res(77)31\&Language=lanEnglish\&Ver=original\&Site=CM\&B ackColorlnternet=C3C3C3\&BackColorIntranet=EDB021\&BackColorLogged $=F$ 5D383>, accesed 13 December 2015.

Dragos, D. C. and Neamtu, B. (2014). Alternative Dispute Resolution in European Administrative Law. Berlin, Heidelberg: Springer.

European Convention for the Protection of Human Rights and Fundamental Freedoms. (1950). At <http://www.varuh-rs.si/pravni-okvir-in-pristojnosti/ mednarodni-pravni-akti-s-podrocja-clovekovih-pravic/>, accessed 13 February 2018.

European Ombudsman. (2013). European Code of Good Administrative Behaviour. At <from https://www.ombudsman.europa.eu/sl/publication/ en/3510\#/page/Y>, accessed 14 March 2018.

European Parliament resolution of 15 January 2013 with recommendations to the Commission on a Law of Administrative Procedure of the European Union (2012/2024(INL)). At <http://www.europarl.europa.eu/sides/getDoc. do?pubRef=-//EP//TEXT+TA+P7-TA-2013-0004+0+DOC+XML+V0//SL>, accessed 2 December 2015.

Grad, F., Kaučič, I., Ribičič, C. and Kristan, I. (1996). Državna ureditev Slovenije. Ljubljana: Official Gazette of the Republic of Slovenia.

Harlow, C. and Rawlings, R. (2009). Law and Administration. Cambridge: Cambridge University Press.

Human Rights Ombudsman Act (ZVarCP). Official Gazette of the Republic of Slovenia, nos. 71/1993, 15/1994 - corr., 56/2002 - ZJU, 109/2012, 54/2017.

Human Rights Ombudsman of the Republic of Slovenia. (2014). Annual report of the Human Rights Ombudsman of the Republic of Slovenia for 2013. Ljubljana.

Human Rights Ombudsman of the Republic of Slovenia. (2015). Annual report of the Human Rights Ombudsman of the Republic of Slovenia for 2014. Ljubljana. 
Human Rights Ombudsman of the Republic of Slovenia. (2016). Annual report of the Human Rights Ombudsman of the Republic of Slovenia for 2015. Ljubljana.

Human Rights Ombudsman of the Republic of Slovenia. (2017). Annual report of the Human Rights Ombudsman of the Republic of Slovenia for 2016. Ljubljana.

Human Rights Ombudsman of the Republic of Slovenia. (2018). Annual report of the Human Rights Ombudsman of the Republic of Slovenia for 2017. Ljubljana.

Kaučič, I. (2008). Človekove pravice in svoboščine. In A. Kozarov, ed., Ustavna ureditev Slovenije. Ljubljana: GV Založba, pp. 97-173.

Kocjančič, R. (2009). Človekove pravice in temeljne svoboščine. In R. Kocjančič, Ustavno pravo Slovenije. Ljubljana: Faculty of Administration, pp. 97-145.

Koprić, I., Musa, A. and Lalić, N. G. (2011). Good administration as a ticket to the European Administrative Space. At <http://hrcak.srce.hr/index. php?show=clanak\&id_clanak_jezik=110642>, accessed 2 December 2015.

Kovač, P. and Leben, A. (2015). Dobra uprava v praksi izbranih enot slovenske javne uprave. In A. Aristovnik, ed., Slovenski javni sektor na razpotju strateških sprememb:zbornik prispevkov, XXII. Dnevi slovenske uprave. Ljubljana: Faculty of Administration.

Kovač, P. and Sever, T. (2016). Sistemski vidiki razumevanja koncepta odprave administrativnih ovir. At< http://www.fu.uni-lj.si/fileadmin/usr-files/Zalozba/ slike/eZbornik-DSU2016.pdf>, accessed 18 May 2018.

Kovač, P. (2012). Ethics of Officials in the Context of (Slovene) Good Administration. The NISPAcee Journal of Public Administration and Policy, 5(1), pp. 23-53.

Kovač, P. (2016). Izzivi alternativnega reševanja sporov v upravnih razmerjih v Sloveniji in širše. Zbornik znanstvenih razprav, 76. At <http://www.pf.uni-lj.si/ media/zzr2016_kovac.pdf>, accessed 15 November 2016.

Kucsko-Stadlmayer, G. (2008). European Ombudsman Institutions. A comparative legal analysis regarding the multifaceted realisation. Vienna, New York: Springer.

Lozina, D. and Klarić, M. (2012). "Dobra uprava” kao upravna doktrina u europskoj uniji. At <http://hrcak.srce.hr/index.php?show=clanak\&id_clanak_ jezik=179005>, accessed 15 November 2015.

Pečarič, M. (2008). Uradništvo med formalnim in neformalnim vplivom na politiko in državljane. Ljubljana: Official Gazette of the Republic of Slovenia.

Pečarič, M. (2011). Osnove javne uprave. Ljubljana: Študentska založba.

Pečarič, M. (2016). Alternative dispute resolution in administrative law - the Slovene perspective. In Spreading standards, building capacities : European administrative space in progress. Zagreb: NISPAcee. At <http://www.nispa. org/conf_paper_details2016.php?cid=24\&p=3559\&pid=5822>, accessed 15 April 2016.

Public Administration Development Strategy 2015-2020. (2015). At <http:// www.mju.gov.si/si/delovna_podrocja/kakovost_v_javni_upravi/strategija_ razvoja_javne_uprave>, accessed 12 September 2015.

Reif, L. (2004). The Ombudsman, Good Governance and the International Human Rights System. Leiden: Kominklijke Brill NV. 
Remac, M. (2013). Standards of Ombudsman Assessment: A New Normative Concept. At <http://papers.ssrn.com/sol3/papers.cfm?abstract_id=229437>, accessed 27 December 2015.

Remac, M. (2014). Coordinating ombudsmen and the judiciary. A comparative view on the relations between ombudsmen and the judiciary in the Netherlands, England and the European Union. At <http://dspace.library. uu.nl/handle/1874/290371>, accessed 20 December 2015.

Rovšek, J. (2002). Neformalni mehanizmi varstva človekovih pravic-ombudsmani in varuh človekovih pravic. In M. Cerar, J. Jamnikar and M. Smrkolj, eds., Dokumenti človekovih pravic z uvodnimi pojasnili. Ljubljana: Amnesty International Slovenia, Peace Institute, pp. 127-145.

Rovšek, J. (2013). Od ustave do zakona o varuhu človekovih pravic. In J. Rovšek and L. Kalčina, eds., 20 let Zakona o varuhu človekovih pravic 1993-2013. Ljubljana: Human Rights Ombudsman, pp. 11-26.

Teršek, A. (2014). Teorija legitimnosti in sodbno ustavništvo. Koper: Univerzitetna založba Annales.

The European Ombudsman. (1999). The European Ombudsman annual report for 1998. Strasbourg: The European Ombudsman.

Tomaževič, N. and Aristovnik, A. (2015). Povezanost zadovoljstva zaposlenih z elementi dobre uprave: primer slovenske javne. In A. Aristovnik, ed., Slovenski javni sektor na razpotju strateških sprememb: zbornik prispevkov, XXII. Dnevi slovenske uprave. Ljubljana: Faculty of Administration.

Treaty on European Union (OJ C 115, 9 May 2008 and OJ UL C 290, 30 November 2009).

Treaty on the Functioning of the European Union (OJ C 115, 9 May 2008 and OJ UL C 290, 30 November 2009, Official Gazette of the Republic of Slovenia, no. 15/2010).

Venice Commission (European Commission for Democracy through Law). (9 April 2011). Stocktaking on the Notions of "Good Governance" and "Good Administration", Study no. 470/2008, CDL (2011)006. At <http://www.venice. coe.int/webforms/documents/default.aspx?pdffile=CDL(2011)006-e>, accessed 17 May 2018. 